\title{
NATIVE STOOLS ON THE GOLD COAST
}

A Distinctive feature in land cases on the Gold Coast is the frequent reference to the stool to which the land is attached, and in cases where the rival parties are chiefs the question is not whether the land belongs to this or that chief but whether it is attached to this or that stool.

This stool is usually a low, curved seat supported on four legs and a hollow cylinder in the centre, the legs and wall of the cylinder resting on a flat base. It is carved out of a single piece of wood, light wood being used so that the stool may not be too heavy for one man to carry.

For Europeans fancy stools are often made having supports fashioned after the form of alligators, elephants and other animals. There is, however, nothing sacred about the form of the stool and any native who can afford it may have one for ordinary use, provided he does not copy some peculiarity of a "family" stool, and with market women the most popular sort of seat is a tiny stool.

The origin of stools is lost in antiquity. They are probably connected with the idea of sacrifice. In countries east of the Gold Coast sacrificial seats are actually in use, the priest sitting astride whilst he cuts the victim's throat across the edge of the seat. It is not possible to trace any such practice on the Gold Coast ; on the other hand the customary smearing of family and tribal stools with blood points to the connection of the stool with sacrificial rites, whilst the close relationship in early times between the offices of chief and priest would account for the stool being now regarded as the symbol of headship. Only this vague conjecture can here be offered, but it should not be difficult for educated natives fully acquainted with their language and customs to throw valuable light on the subject. 


\section{[To face preze 290.}

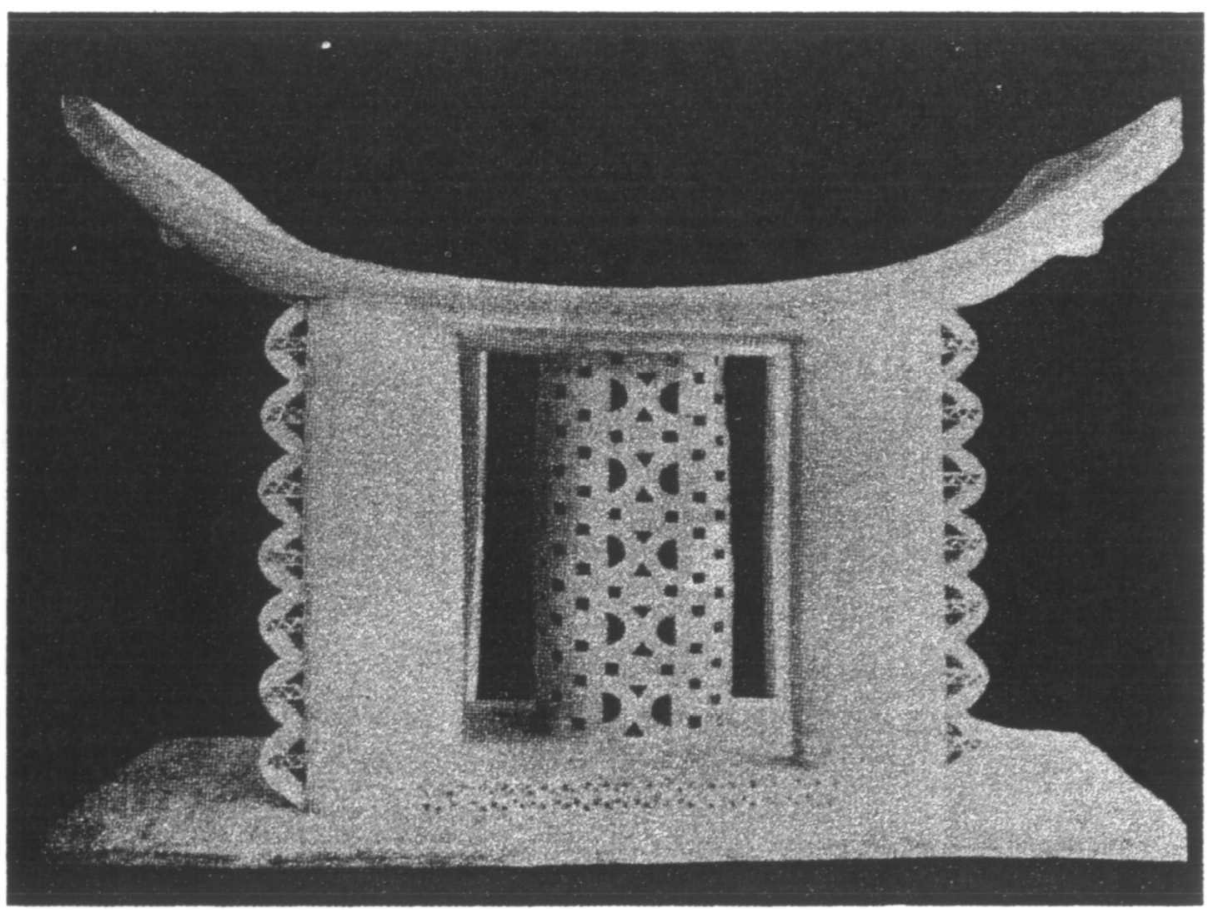

A Native Stool. 
- 
[To face Mure 291.

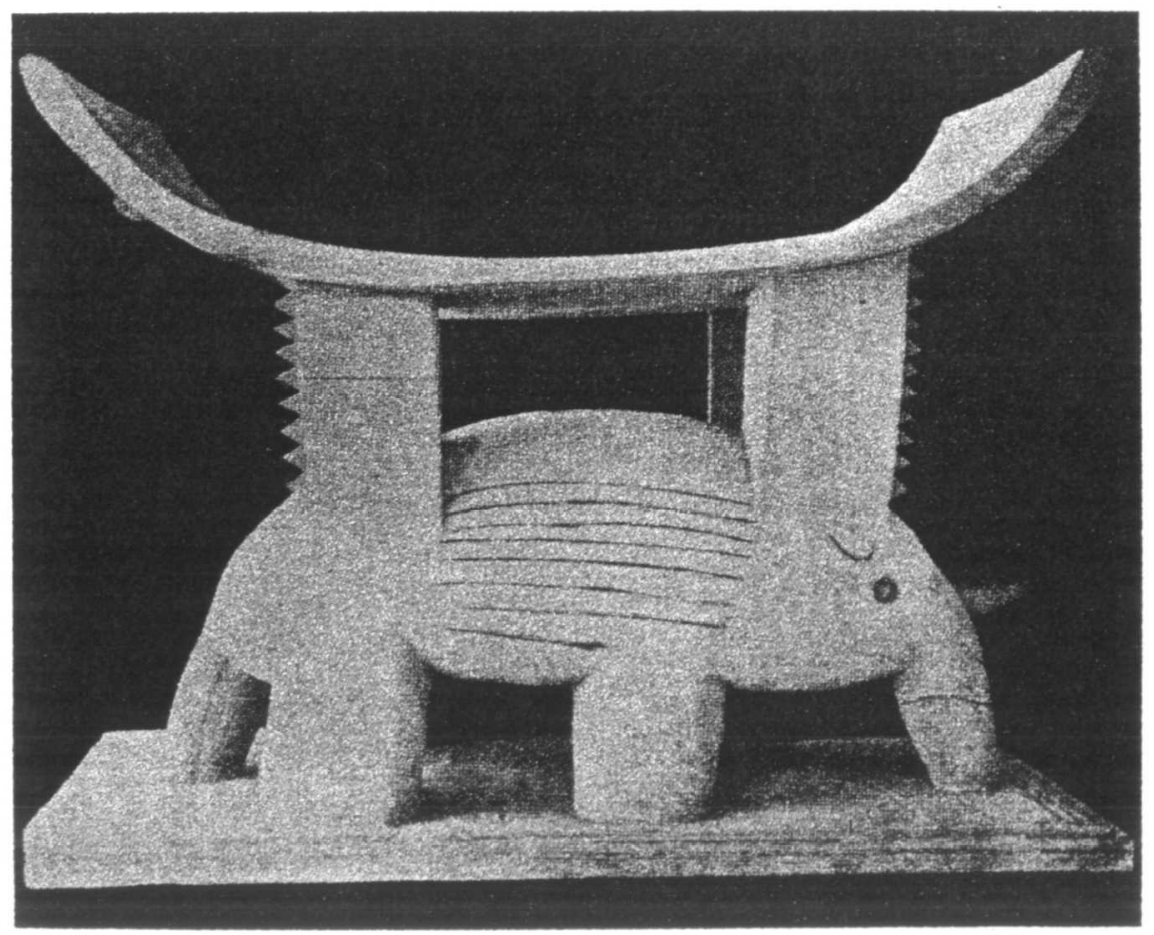

A Fancy Native Stool. 
If a family desires to have a stool, application is made to the chief of the tribe or the immediate subchief of the applicant. The stool may be presented by the chief or subchief; if not, one has to be obtained at a cost of ten to twenty shillings from professional stoolmakers. The stool having been procured, the elders of the family place on the stool the person who represents the head of the family. In past times, not so many decades ago, the stool would have been consecrated by a human sacrifice, the blood of the victim being used to darken the stool, but now a sheep has to suffice. The stool is not formally endowed with anything, but when once accepted as the family stool it is regarded as the actual owner of all family lands and of all personalty and slaves. Everything which is acquired by the family subsequently also becomes stool property. The stool is above the fetish of the family, and it is the stool, and not the person on it, which the family or tribe serves. The person who is strictly head of the family can always be ascertained, and if suitable and willing to take office he (or she sometimes) is placed on the stool and is then recognised as the head. But it often happens that another member is put on the stool, and in such a case, such member becomes ipso facto head of the family because he is on the stool. At times it happens that for a long period no one is elected to the stool, in such case one of the elders is placed in charge of the stool and he has temporarily all the powers of the head of the family or tribe.

Originally ownership of a stool was regarded as entitling the owner to all property possessed by such stool. And the idea is not yet extinct. Some years ago in the Volta River District a stool worth intrinsically a few shillings was sold in execution for about $£ 50$ by reason of there being sundry lands attached to it, and the purchaser of the stool entered into possession of the stool lands without hindrance. But such a case rarely occurs, as rather than let their stool be sold the various members of the family will borrow to their utmost limit, and in days gone by would have preferred to pawn themselves, beginning with the younger members of the family nearest to the stool. The stool is liable for debts incurred by the family and sometimes it is pawned, but no 
lapse of years prevents its redemption. In the ABIRRIU case, the chief of ABIRrJu having pawned his stool and the family never being able to redeem it, the head chief gave the family a new one, but the townspeople refused to serve the new stool, and consequently the chief's family had to found a new village under the new stool, so that there are now two AbIrRIUS.

Where a chief is destooled by his people and feels aggrieved, he sometimes retains the stool and the stool paraphernalia, and thus prevents the due enstoolment of the chief selected in his stead. Until lately, when the Government took into its own hands the question of who was entitled to the stool, this was a fruitful source of litigation, and even when the Court decided against a recalcitrant ex-chief he would sometimes prefer to linger for years in gaol by way of contempt of court rather than give up the stool. In such a case it would be permissible to make a new stool. ${ }^{1}$

Amongst Europeans a native stool goes by the name of Ashanti stool, probably because many specimens were brought home by officers from the Ashanti expedition of I874.

In the Tchi language stool is Agwa. Abrogma ( - AbroFOAGWA) is whiteman's stool, i.e. chair. APUNGWA, or darkened stool, darkened not by age but by blood, is the principal stool of a tribe. When a chief has in his own estimation distinguished himself and desires his name to be perpetuated, he causes a stool to be made and placed with the APUNGWA and henceforward such new stool is kept with the APUNGWA and associated with his name. These chiefs' stools are also called APUNGwA, but they are not on a level with the original APUNGWA which is usually styled the APUNGWA.

In the AKWAPn country the stools are kept in a special room in the compound of the OMaNHIN (father of his country, i.e. headchief), each stool being wrapped in its own cloth, a sort of blanket made by the Hausas of the interior. Every

I A bill we pased by the Legiletive Counell of the Gold Const on Dec. 3oth, Igas which seems to meet with the approval of enlightened native opinion. It enable - District Commistioner on the strength of sworn evidence to isue a pablic arder for the itool property to be given ap, and to serve anspected perrons with a notice to sppear before the court, and there delive up atool property in their custody. 
forty days comes an ADA or minor festival, when the stool attendants, about eighteen in number and who are also the stool carriers, enter the room and see that the stools and their cloths are in order. The stool attendants on this occasion also bring in the actual stool on which the OMANHIN sits and pour rum on it for the others; the rest they sprinkle with blood, but not with human blood.

At the annual Yam custom all the stools are brought out from their little chamber to a large adjoining room where each stool is uncovered and placed on its own cloth, the Apungwa being set in the middle. The stools may now be viewed by the linguists and councillors and office holders and their families, but not by everybody. When the OmanhiN, during this festival, parades the town in state he is preceded by the APUNGwa enveloped in its cloth and shaded by its own magnificent coloured umbrella. The stools remain in the outer room for a week or ten days, and each day two or three sheep are sacrificed to them, the blood being sprinkled over the stools whilst the carcases go as perquisites to the stool attendants. Several times during the festival the Oxanhin surrounded by his hornblowers and the beaters of the small drums sits on the APUNGWA in the outer chamber whilst the head attendant calls out the name of each stool, beginning from the first, and at the mention of each name the head attendant pours out a libation of rum and calls on the holder of that stool to bless the present holder, i.e. the Omanhin. When the Omanhin goes to war the APUNGwA wrapped in its cloth precedes him and is under the special charge of a captain and company.

The most famous of native stools is the golden stool of Ashanti, or to be more correct of the King of Kumasi, the attempt to capture which was the proximate cause of the late Ashanti war. Hearsay states that the stool is not made of gold but that it is only plated with gold and that in places where the wood has broken or worn away it has been repaired with gold. Along with it, inside the hollow cylinder, would probably be found aggrey beds, gold ornaments used in connection with the enstooling of a new king and, most interesting of all, the " notes" or " books" which Brandenburgers, 
Danes, Dutch, English, Portuguese and Swedes gave for the various forts which at different times they held on the Gold Coast and which the Ashanti kings captured from their original holders. Rightly or wrongly many people hold that so long as this stool is outstanding so long will the Ashantis feel that they have not been conquered. But the regular administration of justice, the good government of the country and the railway to Kumasi will effect more than many wars and probably at no distant date the holders of the stool will gladly part with it for the value of the gold in which it is encased.

And lastly the Governor of the Gold Coast has his state chair or " stool." It is an old, gilded, high-backed chair with the Dutch arms embroidered on the back. - It was the state chair of the Dutch Governors of Elmina and with Elmina Castle passed to the British in 1867. It was subsequently brought to Accra, the headquarters of the Government, and is now used by the Governor on state occasions and when sitting in council. It is to be hoped that when at length the golden stool of Ashanti comes to be handed over to the Government it will not be sent home to be placed alongside the golden axe in South Kensington Museum, rather that it will be kept in its own country and used as the state chair of the Chief Commissioner at Kumasi.

W. BrandFord GRIfFith. 
[To face page 294.

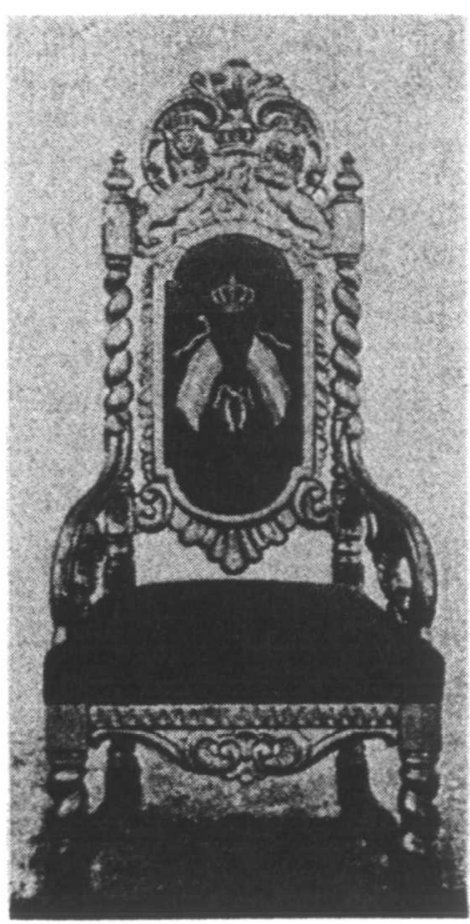

The Guvernok's Stool. 

